the baboons, which eat insects largely, are much more cautious in receiving any food than is the Cercopithecus.

\title{
20. Conclusions from Experiments on Captive Baboons, Mungoose, and Kestrels. (G. A. K. M.)
}

[Mr. Marshall's notes on these insectivorous animals were in one series, which I have analyzed for the purpose of this memoir. Hence the following references in his letters deal with the experiments as a whole, except in those instances in which a particular animal is named.-E. B. P.]

Salisbury, June 20, 1899.-In view of the above experiments it seems to me impossible to regard such genera as Terias, Teracolus, Belenois, Byblia, etc. as unpalatable. I quite agree with your excellent suggestion that distasteful characters probably first arose in the larval stage and were transmitted to the imago, and this view lends further support to the presumed palatability of Belenois, for my baboon ate the larvæ with much relish. Teracolus likewise I must still regard as a non-distasteful genus, at least so far as the orange- and purple-tipped groups are concerned.

I was much pleased with the undoubted proof of mimicry [in the experiments with baboons] in the case of Precis sesamus $\bigoplus$, for I do not recollect having seen an account of direct experimental proof before.

With Byblia I was not so successful as I had hoped, but I am inclined to attribute the hesitation in accepting this species, which was observed in some instances, to imperfect mimicry. I fully recognize the difficulty in distinguishing in such experiments between Batesian and slightly Miillerian mimics, as either might be received with hesitation at first, though if subsequent specimens were eaten readily (as in the case of Byblia) I should think they must be included in the former category.

The eager acceptance of the malodorous Coreid bugs by my baboons came as a very great surprise to me, and several other results in these experiments point to the great danger of generalizing on the unpalatability or otherwise of insects, from the results of experiments on only one kind of animal.

Salishury, April 25, 1899.-I may mention that so far as my experiments go I have no evidence for the unpalatability of Terias, Teracolus, Belenois, Byblia, Precis, or Hypolimnas, whereas Mylothris and Neptis are certainly distasteful to some extent. 

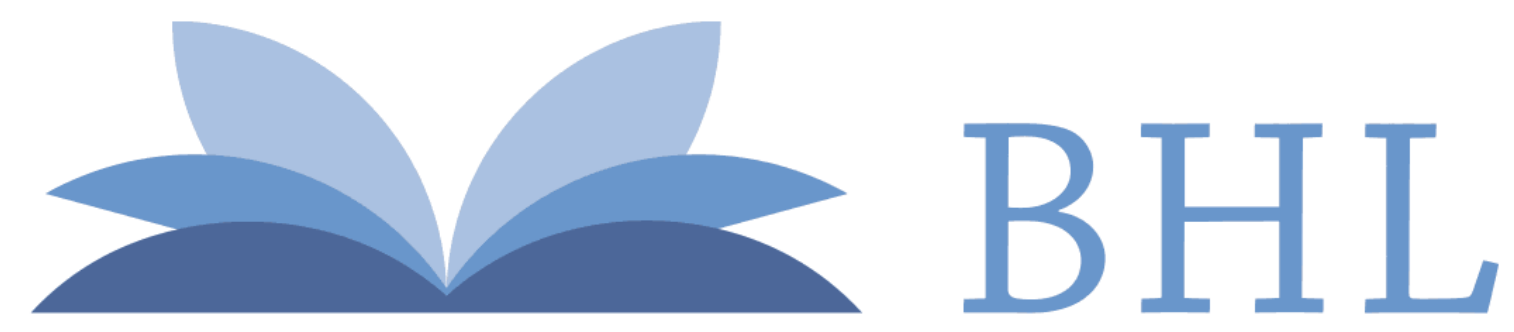

\section{Biodiversity Heritage Library}

1902. "20. Conclusions from Experiments on Captive Baboons, Mungoose, and Kestrels. (G. A. K. M.)." Transactions of the Entomological Society of London 50, 387-387. https://doi.org/10.1111/j.1365-2311.1902.tb02411.x.

View This Item Online: https://www.biodiversitylibrary.org/item/48243

DOI: https://doi.org/10.1111/j.1365-2311.1902.tb02411.x

Permalink: https://www.biodiversitylibrary.org/partpdf/25262

\section{Holding Institution}

Smithsonian Libraries

\section{Sponsored by}

Smithsonian

\section{Copyright \& Reuse}

Copyright Status: Public domain. The BHL considers that this work is no longer under copyright protection.

This document was created from content at the Biodiversity Heritage Library, the world's largest open access digital library for biodiversity literature and archives. Visit BHL at https://www.biodiversitylibrary.org. 